University of Nebraska - Lincoln

DigitalCommons@University of Nebraska - Lincoln

Publications from USDA-ARS / UNL Faculty

U.S. Department of Agriculture: Agricultural

Research Service, Lincoln, Nebraska

2020

Forage Systems for the Temperate Subhumid and Semiarid Areas

John R. Hendrickson

Corey Moffet

Follow this and additional works at: https://digitalcommons.unl.edu/usdaarsfacpub

Part of the Agriculture Commons

This Article is brought to you for free and open access by the U.S. Department of Agriculture: Agricultural Research Service, Lincoln, Nebraska at DigitalCommons@University of Nebraska - Lincoln. It has been accepted for inclusion in Publications from USDA-ARS / UNL Faculty by an authorized administrator of DigitalCommons@University of Nebraska - Lincoln. 


\title{
Chapter
}

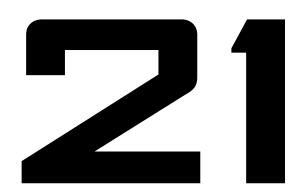

\section{Forage Systems for the Temperate Subhumid and Semiarid Areas}

\author{
John R. Hendrickson, Research Rangeland Management Specialist, \\ USDA-Agricultural Research Service, Mandan, ND, USA \\ Corey Moffet, Research Rangeland Management Specialist, \\ USDA-Agricultural Research Service, Woodward, OK, USA
}

\section{Introduction}

Within North America, a majority of the temperate subhumid and semiarid zones are in the Great Plains. The defining factor separating the two zones is precipitation effectiveness (PE), which considers both precipitation and evaporation. Thornthwaite (1931) used this index to identify six different PE zones in North America. Historically, the separation between the subhumid and semiarid zones runs roughly along the $100^{\text {th }}$ meridian (Thornthwaite 1941). However, more recent characterizations have moved both the semiarid and dry subhumid zones to the west (Figure 21.1). Using more recent data, the dry and moist subhumid zones lie roughly astride the $100^{\text {th }}$ meridian with the moist subhumid zone to the east (Figure 21.1). The temperate subhumid zone comprises several million hectares (Table 21.1) and includes nearly-half of Texas, most of Oklahoma, Kansas, Nebraska, and the Dakotas and the western half of Minnesota (Figure 21.1). The temperate semiarid zone lies to the west and includes the eastern parts of Montana, Wyoming, Colorado, New Mexico, and west Texas (Figure 21.1). However, for this chapter, we will generally use the historical designations for subhumid and semiarid, which considers the $100^{\text {th }}$ meridian as the delineator.
The Great Plains is a large expanse of land reaching from Mexico, across the interior of the United States and up into Canada (Trimble 1980). It stretches from the eastern slopes of the Rocky Mountains to the edge of the tallgrass prairie (Trimble 1980; Padbury et al. 2002). Elevation ranges from $1250 \mathrm{~m}$ along the Rockies to $300 \mathrm{~m}$ on their eastern border (Padbury et al. 2002). The Great Plains is generally characterized by gently rolling plains occasionally interrupted by wide river valleys, hills, or badlands (Padbury et al. 2002). The glaciated areas of the Northern Great Plains less variation in topography than the non-glaciated areas further south (Padbury et al. 2002). Although dominated by gently rolling landscapes, there are distinct geologic features contained within the region. These include the Black Hills of South Dakota, the Sandhills of Nebraska, the Flint Hills of Kansas, and the Edwards Plateau in Texas.

Within the Great Plains states, land use can vary widely. For example, Minnesota, has only $7.2 \%$ of its total land in farms being used as pasture or rangeland (Table 21.1). In contrast, over $90 \%$ of the total farmland in Wyoming and New Mexico is in pasture and rangeland. It is important to note that the western Great Plains states (Montana, Wyoming, Colorado, and New Mexico) are drier and the Great Plains geographic region does not cover the states

Forages: The Science of Grassland Agriculture, Volume II, Seventh Edition.

Edited by Kenneth J. Moore, Michael Collins, C. Jerry Nelson and Daren D. Redfearn.

(C) 2020 John Wiley \& Sons Ltd. Published 2020 by John Wiley \& Sons Ltd. 


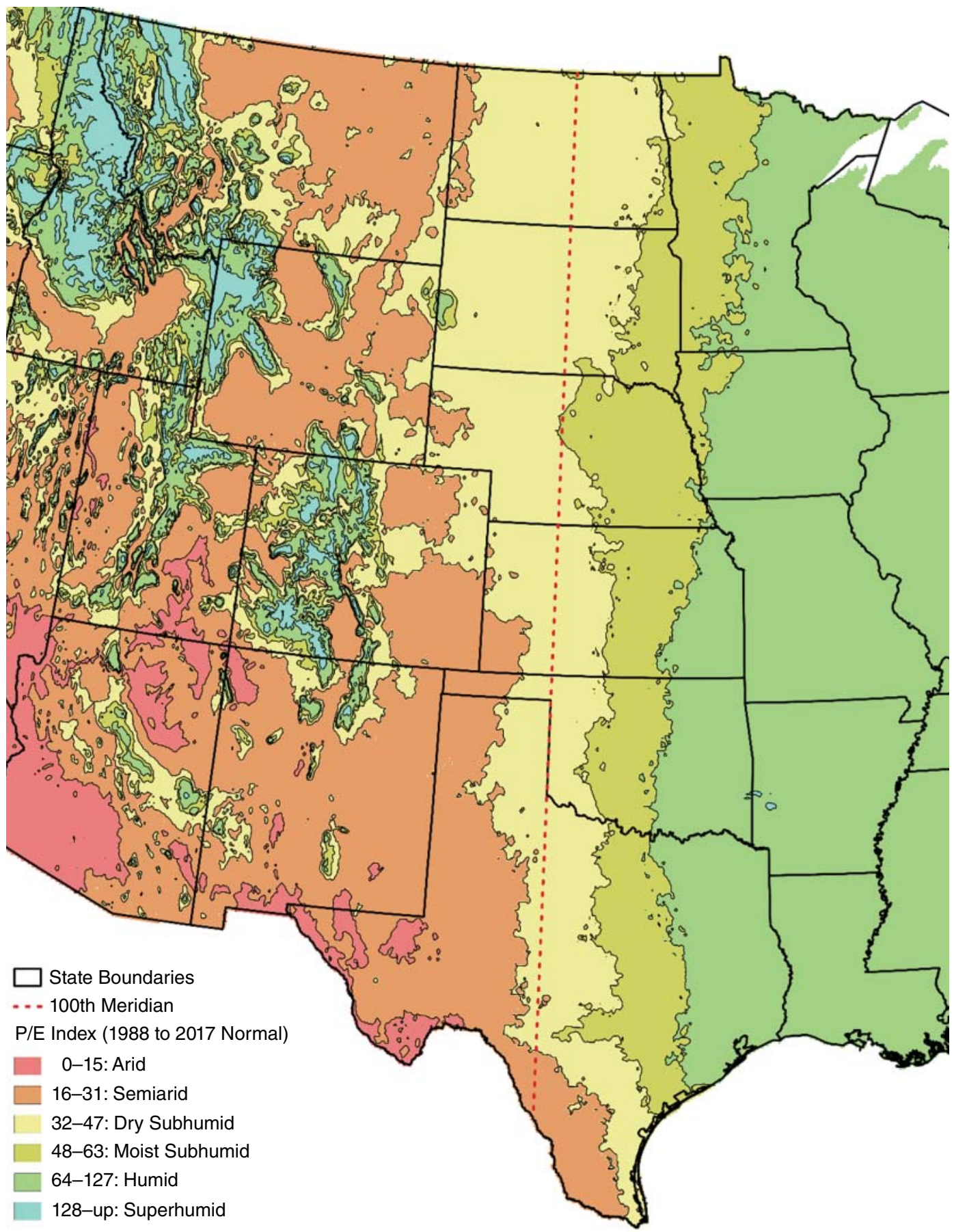

FIG. 21.1. Map of the central part of the United States including the Great Plains showing climatic classifications developed using the P/E index (Thornthwaite 1931) from climatic data from 1988 to 2017. Source: Figure developed by C. Moffet. 
Table 21.1 Land use for states in the temperate subhumid and temperate semiarid regions (ha)

\begin{tabular}{lrrrrr}
\hline State & $\begin{array}{l}\text { Pasture/grazingland } \\
\text { that could be } \\
\text { used for crops }\end{array}$ & $\begin{array}{l}\text { Grassland/ } \\
\text { rangeland }\end{array}$ & $\begin{array}{l}\text { Pastured } \\
\text { woodland }\end{array}$ & $\begin{array}{l}\text { Total } \\
\text { pastureland }\end{array}$ & $\begin{array}{l}\text { Pastureland as a } \\
\text { percent of total } \\
\text { farmland }\end{array}$ \\
\hline Colorado & 427615 & 19223470 & 826838 & 20477923 & 64.2 \\
Kansas & 442258 & 15525646 & 308408 & 16276312 & 35.4 \\
Minnesota & 167026 & 1271242 & 439332 & 1877600 & 7.2 \\
Montana & 910532 & 39298812 & 1962724 & 42172068 & 70.6 \\
Nebraska & 322093 & 22297424 & 212929 & 22832446 & 50.4 \\
New Mexico & 229591 & 37973029 & 2163280 & 40365900 & 93.4 \\
North Dakota & 321936 & 10247184 & 125002 & 10694122 & 27.2 \\
Oklahoma & 1001543 & 19451870 & 1731414 & 22184827 & 64.5 \\
South Dakota & 518702 & 22545069 & 180751 & 23244522 & 53.7 \\
Texas & 2845326 & 90287767 & 5759183 & 98892276 & 76.0 \\
Wyoming & 282997 & 27203663 & 360419 & 27847079 & 91.7 \\
Total & 7469619 & 305325176 & 14070280 & 326865075 & 61.7 \\
US total & 12802847 & 415309280 & 27999006 & 456111133 & 49.9 \\
\% US total & 48 & 61 & 32 & & 55 \\
\hline
\end{tabular}

Source: USDA-NASS (2014).

entirely. Doing so, would increase the percentage of total farmland that is devoted to pasture and rangeland. The percentage of land in pasture and rangeland can be influenced by the distinct geologic features mentioned earlier, but is primarily determined by climate.

\section{Climate}

Climate is the primary factor influencing forage systems in the temperate subhumid and semiarid zones. Climate determines the length of the growing season, biomass productivity and type of crops suitable for incorporating into forage systems. There are two climatic trends in the Great Plains that influence the management of forage systems. First, the length of the growing season decreases from south to north. For example, in southern areas of the temperate subhumid and semiarid zones, the frost-free period can range from 210 to 240 days (Orton 1974), but in the most northern areas, the frost-free period is usually only 90-120 days (Bavendick 1974). Because of the short growing season and the need to feed hay for significant parts of the year, hay quantity and nutritive value become especially important considerations in the Northern Great Plains (Lorenz 1976). Second, in the Plains states, precipitation often decreases from east to west, resulting in productivity per unit area often following the same trend. Increased precipitation in the eastern part of the Great Plains often results in a higher percentage of farmland being used for cropland, whereas in the Western Great Plains a greater percentage of the farmland is used for pastures (USDA 2014). In areas with mixed livestock and grain production, crop aftermath (corn or wheat stubble) can be used to meet forage needs, especially in the fall and winter.
Within both zones, the most significant attribute associated with climate is variability. Precipitation and temperature can show large variations not only spatially but also annually and even diurnally. Coping with this variation is a serious challenge for producers in the temperate semiarid region (Padbury et al. 2002).

\section{Soils}

Most soils in the temperate subhumid and semiarid zones are Mollisols, which are typical of soils that have developed under predominantly grassland vegetation (Soil Survey Staff 1999). Mollisols are thick, dark-colored soils with high-base saturation $(>50 \%)$ that have organic-rich surface horizons and well-developed structure; they are not massive or hard when dry (Foth 1984). The high-natural fertility of Mollisols makes them desirable for crop production, though continuous cultivation has caused serious structural and erosion problems in some areas (Brady and Weil 1999). Mollisols are found from central Texas north into the Dakotas and Canada (Brady and Weil 1999). Other soil orders in the region include the less developed Entisols and Inceptisols, the more developed Alfisols, with their clay accumulation in the subsoil, the clayey shrinking and swelling Vertisols, and the dry Aridisols along the western edge of the region.

\section{Livestock}

\section{Beef Cattle}

Beef cattle far outnumber all other kinds of livestock combined in both the temperate subhumid and temperate semiarid regions (Table 21.2). In 2012, beef cattle made up over $75 \%$ of the ruminant livestock in the Great Plains, 
Table 21.2 Beef cattle, dairy cattle, and sheep inventory of selected states for 1992 and 2012 (head)

\begin{tabular}{|c|c|c|c|c|c|c|}
\hline \multirow[b]{2}{*}{ State } & \multicolumn{2}{|c|}{ Beef } & \multicolumn{2}{|c|}{ Dairy } & \multicolumn{2}{|c|}{ Sheep } \\
\hline & 1992 & 2012 & 1992 & 2012 & 1992 & 2012 \\
\hline Colorado & 900347 & 683291 & 81825 & 130736 & 730272 & 401376 \\
\hline Kansas & 1434017 & 1270538 & 85132 & 131688 & 206566 & 62541 \\
\hline Minnesota & 381869 & 357826 & 609034 & 463312 & 221777 & 126506 \\
\hline Montana & 1506445 & 1439653 & 22409 & 13947 & 634361 & 236646 \\
\hline Nebraska & 1857347 & 1730112 & 83295 & 54628 & 151777 & 71771 \\
\hline New Mexico & 631738 & 461595 & 110422 & 318878 & 460700 & 89745 \\
\hline North Dakota & 837716 & 881662 & 74885 & 17876 & 217240 & 64607 \\
\hline Oklahoma & 1728273 & 1677903 & 90312 & 45885 & 103732 & 53738 \\
\hline South Dakota & 1604838 & 1610559 & 117454 & 91831 & 661872 & 257676 \\
\hline Texas & 5186359 & 4329341 & 394587 & 434928 & 2223774 & 623000 \\
\hline Wyoming & 748789 & 664254 & 7596 & 6194 & 921133 & 354785 \\
\hline Total & 16817738 & 15106734 & 1676951 & 1709903 & 6533204 & 2342391 \\
\hline US total & 32545976 & 28956553 & 9491818 & 9252272 & 10770391 & 5364844 \\
\hline$\%$ US total & 52 & 52 & 18 & 18 & 61 & 44 \\
\hline
\end{tabular}

Source: USDA-NASS (2014).

which was greater than the $67 \%$ of ruminant livestock in 1994. The number of beef cattle has declined by about $11 \%$ over the last 20 years but data from 2018 (USDA-NASS 2019) shows national and regional beef numbers increasing to close to 1994 levels. The low beef cattle numbers in the 2012 Census of Agriculture were probably a result of the severe drought, which started in the Southern Great Plains in 2011 and spread north in 2012. Cow-calf production is common throughout both the temperate subhumid and temperate semiarid regions and cattle are grazed on both private and publicly held lands. Yearling or stocker cattle operations, however, are more prevalent in the temperate subhumid region.

\section{Dairy Cattle}

Dairy cattle numbers increased in Colorado, Kansas, New Mexico, and Texas but decreased in the remainder of the Great Plains during the 20-year period from 1992 to 2012 (Table 19.2). While the number of dairies is increasing in some nontraditional milk-producing areas, such as the western states, due to reduced land and labor costs, the overall number of dairy farms in the United States is decreasing, while the overall size of the farms has grown (Blayney 2002). The decline in dairy cow numbers was especially dramatic in North Dakota which saw a reduction of over $75 \%$ during the 20 -year period between 1992 and 2012.

\section{Sheep and Goats}

The loss of the wool and mohair subsidy as part of the Farm Bill of 1996 resulted in a reduction in sheep and goat production. Sheep numbers have continued to decrease (Table 21.2) which has been the trend since 1942 when sheep numbers reached a peak of 56.2 million head. Up until 1977, USDA did not provide actual numbers for goats, but merely grouped goats with the sheep. The USDA annual reports indicate the number of angora goats clipped for mohair has decreased from almost 2 million head in 1992 to slightly less than 155000 in 2012. Over $47 \%$ of the angora goats produced in 2012 were raised in Texas (USDA-NASS 2014). Meat goats have increased dramatically during the same period from 591543 in 1992 peaking at 2601669 in 2007 and declining to 2053228 in 2012 . Meat goats may be found in many states contained within the temperate subhumid and temperate semiarid regions. Texas, California, and Missouri reported the largest goat inventory in 2012 (USDA-NASS, Quick Stats 2019).

\section{Horses}

Horses are prevalent throughout the temperate subhumid and temperate semiarid regions, both for pleasure and work. There were over 3 million horses and ponies in the US in 2012 (USDA-NASS 2014). Between 45\% and $60 \%$ of horses were owned for recreation (Raub 2018) suggesting that people own horses for pleasure. This impacts their thoughts about forage and grazing management. Horse numbers have been increasing for several years and this trend is likely to continue.

\section{Important Forage Species}

Additional information on the perennial cool-grasses including the wheatgrasses, wildryes, and other miscellaneous cool-season species can be found in Chapter 17. 


\section{Introduced Cool-Season Forages}

Introduced cool-season forages have always been a critical part of temperate subhumid forage systems in the US. The introduced cool-season forages can be split into annual and perennial species. In the states of the central Great Plains (Texas, Oklahoma, Kansas, Nebraska, and the Dakotas) about 1.8 million acres of annual small grains were harvested for hay in 2012 (USDA-NASS 2014). Besides the small grains harvested for hay, grazing of winter wheat during winter and early spring is a common practice from Kansas to north Texas.

Other cool-season annual forages include annual ryegrass overseeded into warm-season perennial grass sods in the eastern part of the temperate subhumid region or for winter forage in Texas and Oklahoma. Triticale is an option for grazing and remains vegetative longer than wheat. In the northern portion of the temperate subhumid region, primarily North Dakota and Montana, spring barley is used as hay, silage, or occasionally grazed.

Interest in the forage potential of annual cover crops is increasing. The primary focus driving increased use of cover crops is the perceived conservation benefits (Myers and Watts 2015); however, they can also be an important source of livestock forage (Sanderson et al. 2018). Inclusion of legumes in cover-crop mixtures can enhance the forage quality (Hansen et al. 2015; Sanderson et al. 2018). An annual cool-season forage mixture that included a legume had consistently greater nutritional value than did a crested wheatgrass pasture in a study conducted near Sidney, Nebraska (Titlow et al. 2014).

By the early part of the twentieth century, many native grasslands in the Great Plains had either been converted to farmland or were not properly grazed. As a result, by the late 1930s, there were millions of acres of severely eroded or degraded pastures and croplands throughout the Great Plains (Vogel and Hendrickson 2019) but especially in the drier western portion of the region. Before the devastating drought of the 1930s, the only seeds widely available for pasture planting in the Great Plains were timothy and orchardgrass, both of which had poor drought tolerance (Vogel and Hendrickson 2019). Improving the degraded conditions found on croplands and grasslands required utilization of new or improved forage germplasm which was subsequently incorporated into grazing systems.

Both smooth bromegrass and crested wheatgrass were noted for their ability to survive during the 1930s drought (Vogel et al. 1996; Vogel and Hendrickson 2019). 'Lincoln' dairy smooth bromegrass was introduced in 1942 (Vogel and Hendrickson 2019) and has been a major cool-season forage in the Dakotas, Nebraska, Kansas, and northern Oklahoma. Crested wheatgrass, one of the earliest cool-season species to produce forage following winter, is credited for reducing hay use in its area of adaptation. Crested wheatgrass seed was distributed to producers in Wyoming, Montana and the
Dakotas in the 1920s but 'Fairway', released in 1927 by the University of Saskatchewan, was one of the first cultivar releases (Vogel and Hendrickson 2019). Since the release of 'Lincoln' and 'Fairway' there have been 11 new cultivars of smooth bromegrass and 7 cultivars of crested wheatgrass released with the most recent smooth bromegrass release in 2014 and the most recent crested wheatgrass in 2003 (Vogel and Hendrickson 2019).

Other important introduced cool-season perennial forage grasses include intermediate wheatgrass, pubescent wheatgrass, tall wheatgrass, meadow bromegrass, orchardgrass, and creeping foxtail. The wheatgrasses demonstrate good cold tolerance, drought tolerance, and good dry matter production and nutritive value. However, they are relatively short-lived and susceptible to overgrazing (Hendrickson et al. 2005). Although primarily used in the Northern Great Plains, intermediate and pubescent wheatgrass have also been used in the Southern Great Plains to stabilize marginal land formerly in wheat production (Redmon et al. 1995) or to fill gaps between grazing of winter wheat and warm-season pastures (Malinowski et al. 2003). Tall wheatgrass is probably the most productive of all the wheatgrasses, and though coarse at maturity, can produce forage of good nutritive value when managed well (Asay and Jensen 1996). Both tall wheatgrass and intermediate wheatgrass monocultures outperformed switchgrass monocultures on non-irrigated plots in North Dakota (Monono et al. 2013). There have been 12 cultivar releases of intermediate wheatgrass and three releases of tall wheatgrass since 1945 (Vogel and Hendrickson 2019).

Meadow bromegrass is known for early forage production and rapid regrowth (Jensen et al. 2015). Meadow bromegrass produces $49 \%$ more biomass after defoliation than smooth bromegrass (Biligetu and Coulman 2010). While meadow bromegrass is currently best adapted to cooler and more moist areas (Alderson and Sharp 1994), cultivars better adapted to semiarid areas are being developed (Jensen et al. 2015).

Orchardgrass is used to a limited degree in the temperate subhumid region, but does not have the drought tolerance of tall or intermediate wheatgrass. 'Paiute' orchardgrass, which was released by the US Forest Service in 1981, may be the most drought tolerant of the orchardgrass cultivars but even this one generally requires at least $410 \mathrm{~mm}$ of annual precipitation (Bush et al. 2012).

Russian wildrye is a drought-tolerant, grazing-tolerant (Hendrickson and Berdahl 2003) cool-season grass seeded on approximately 400000 ha in the Great Plains of the United States and Canada (Smoliak and Johnston 1980). Once established, russian wildrye provides excellent forage, especially for fall grazing (Lorenz 1977; Smoliak and Johnston 1980). There have been seven cultivars of russian wildrye released since 1960 (Vogel and Hendrickson 2019). 
Both creeping and meadow foxtail are well-adapted in much of the temperate subhumid region. Creeping foxtail has become naturalized across the Great Plains and meadow foxtail across the northern half of the continental United States (Boe and Delaney 1996). Both are adapted to strongly acid and poorly drained soils and are used for pasture, hay, or silage. 'Garrison' creeping foxtail is a common cultivar in the Northern Great Plains.

Legumes can play an important role in forage systems in both the temperate subhumid and semiarid regions. Alfalfa is among the most important forage crops grown in the United States and about $46 \%$ of the United States alfalfa acres are planted in the temperate sub-humid and semi-arid regions. However, most alfalfa hectarage is planted within the northern part of the region (Figure 21.2). Alfalfa is generally used for hay or silage, though there are some grazing-tolerant cultivars available. In the Northern Great Plains, cultivars with a high degree of Medicago sativa subsp. falcata usually persist better under grazing (Bittman and McCartney 1994). In the colder climates of the Northern Great Plains, the ability to withstand the extreme low temperatures may be as important to persistence as the ability to withstand grazing (Hendrickson and Berdahl 2003). Incorporating alfalfa into grasslands increased total yield of the forage system by up to $185 \%$ (Hendrickson et al. 2008a, 2008b), but alfalfa mixtures with cool-season grasses appeared to be more sensitive to early-season water stress than did warm-season grass monocultures (Hendrickson et al. 2013). Alfalfa production in many parts of the Southern Great Plains is severely limited due to the presence of Phymatotrichopsis omnivora in the soil, an ascomycete fungus. The fungus is responsible for Phymatotrichopsis root rot disease (also referred to as cotton root rot or Texas root rot) in alfalfa (Mattupalli et al. 2018).

Other legumes of some importance include birdsfoot trefoil, sweetclover, red clover, and white clover. These legumes, except for sweetclover, do not have the drought

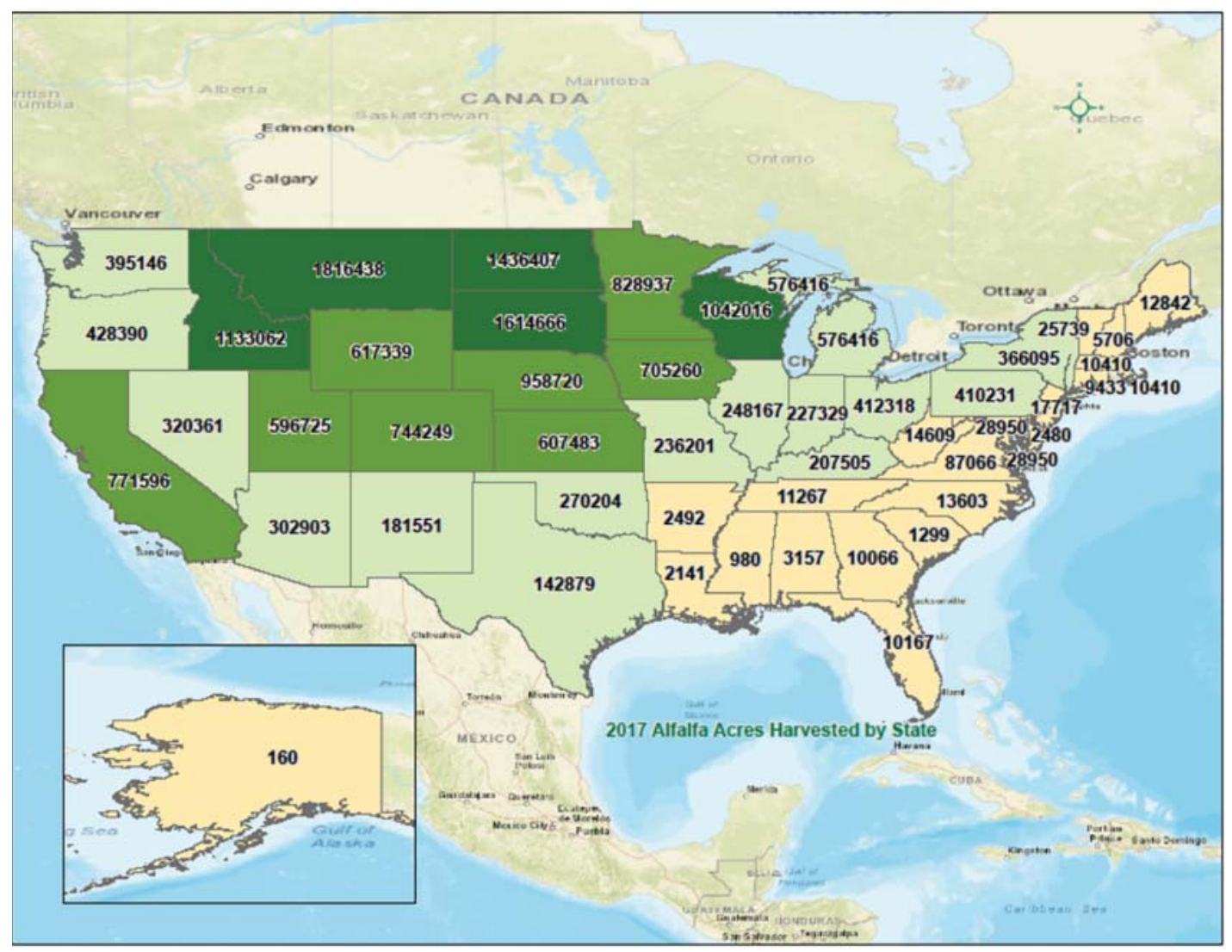

FIG. 21.2. Map of acres (acre $=0.40$ hectares) of alfalfa harvested in each state using data from the 2017 Census of Agriculture (USDA-NASS 2019). The numbers in each state are the number of acres harvested. Darker colored states have the most harvested acres of alfalfa and the lighter colored states have the least. Source: Map developed by J.D. Carter. 
tolerance necessary for production except in the extreme eastern portion of the temperate subhumid region. Sweetclover, which was introduced from Eurasia, has become naturalized in the region and is both drought tolerant and winter hardy.

With more focus on soil health, there has been increased interest in incorporating perennial forages into annual cropping systems. A five-year study in central North Dakota indicated that compared to a continuous wheat cropping system, including perennial forages reduced soil acidity and bulk density and increased particulate organic matter and water-stable aggregates (Liebig et al. 2018). Within the forage treatments, intermediate wheatgrass, alone or combined with alfalfa, reduced soil bulk density and increased particulate organic matter content compared to an alfalfa monoculture (Liebig et al. 2018). The same study indicated having an alfalfa or an alfalfa - intermediate wheatgrass mixture in place for four years reduced the amount of $\mathrm{N}$ needed on a subsequent wheat crop for at least four years (Franco et al. 2018). As soil health receives greater interest, the need for forages to address other aspects besides production and nutritional value will become more important.

\section{Introduced Warm-Season Forages}

Introduced perennial warm-season forages are important on lands dedicated for pasture or hay use. In general, these species are more difficult to establish and have lower nutritive value than annual forage crops, but with proper management and favorable weather, will persist as a dependable source of forage for many years. More information on warm-season forage management can be found in Chapter 17.

Bermudagrass is one of the more important introduced warm-season forage crops in the Southern Great Plains having been introduced to the US from Africa before the US was a country. Bermudagrass is well adapted to a wide range of soil types and soil $\mathrm{pH}$ values. Bermudagrass is an aggressively spreading plant that produces long stolons capable of rooting at nodes in contact with moist soil. The species responds well to fertilizer. There are many cultivars of bermudagrass, and selections of common bermudagrass can be propagated from seed. Hybrid cultivars, however, must be propagated vegetatively by transplanting small pieces of rooted stolons and rhizomes, known as sprigs, dug from an established field typically in the dormant season or soon after breaking dormancy in spring. Many bermudagrass cultivars have limited cold tolerance but 'Goodwell', 'Midland', 'Midland 99', 'Ozark', and 'Tifton 44 ', among the sprigged cultivars, and the seeded 'Guymon' and 'Wrangler' are cold-tolerant cultivars. Often two or more genetic lines or cultivars are included in blends of seeded bermudagrass. Seeded cultivars in south central Oklahoma, averaged over a three-year study, produced between 3400 and $5600 \mathrm{~kg} \mathrm{ha}^{-1}$ without $\mathrm{N}$ fertilizer, and production increased between 9 and $15 \mathrm{~kg} \mathrm{ha}^{-1}$ for every $\mathrm{kg} \mathrm{ha}^{-1}$ of $\mathrm{N}$ applied up to $225 \mathrm{~kg} \mathrm{ha}^{-1}$. Crude protein (CP) and total digestible nutrients (TDNs) also increased with $\mathrm{N}$ applications in this range. The sprigged cultivars were more productive in general and more responsive to the applied N. Non-fertilized production for the sprigged cultivars varied between 5100 and $8500 \mathrm{~kg} \mathrm{ha}^{-1}$ with a $15-19 \mathrm{~kg} \mathrm{ha}^{-1}$ increase in production for every $\mathrm{kg} \mathrm{N} \mathrm{ha}^{-1}$ applied, but the effects of $\mathrm{N}$ fertilizer on nutritive value were similar to the seeded cultivars (Funderburg et al. 2011; Funderburg et al. 2012).

Old-world bluestems include a few warm-season bunch grass species introduced from Eurasia in the 1920s to 1960s. These grasses have good forage potential and have been planted on former cropland soils and along roadside rights-of-ways throughout Oklahoma and Texas. The old-world bluestems are more drought tolerant than bermudagrass and are more likely to be found in the western portions of the region. Several million hectares of old-world bluestem were planted beginning in the mid-1980s on highly erodible lands which had been previously used as cropland. In recent years, concern over the tendency of these grasses to escape the fields and roadsides where they were originally planted has greatly diminished their popularity in new plantings. Old-world bluestems include several selections from the species Bothriochloa ischaemum such as 'Plains' (a blend of 30 different accessions), 'WW-Spar', 'WW Ironmaster', 'King Ranch', and 'Ganada', the selection from Bothriochloa bladhii, 'WW-B. Dahl', and caucasian bluestem or Bothriochloa caucasica. 'WW-Ironmaster' was selected for high $\mathrm{pH}$ soils and is less susceptible to iron chlorosis.

Caucasian bluestem is not as drought tolerant as the other old-world bluestems, but when soil water is adequate, is among the most productive. WW-B. Dahl remains leafy and vegetative later into the growing season but, is less cold tolerant than other cultivars. King Ranch bluestem is also productive in the southern portion of the region, but it too lacks cold tolerance. In a study comparing the response of Plains and B. Dahl old-world bluestems, non-fertilized B. Dahl and Plains old-world bluestems produced more forage than many seeded bermudagrass cultivars and had similar forage production to many of the sprigged bermudagrass cultivars (Funderburg et al. 2011; Funderburg et al. 2012). However, Plains did not respond to added fertilizer N. WW-B. Dahl responded to small amounts of additional $\mathrm{N}, 3200 \mathrm{~kg} \mathrm{ha}^{-1}$ for $76 \mathrm{~kg} \mathrm{ha}^{-1}$ of applied N, but did not respond to greater amounts of $\mathrm{N}$. The $\mathrm{CP}$ and TDN of both old-world bluestem cultivars increased in response to $\mathrm{N}$ application up to $225 \mathrm{~kg} \mathrm{ha}^{-1}$.

Weeping lovegrass was introduced into the US from South Africa during the late 1920s. It is well-adapted to a range of soils, but especially suited to sandy soils where it is important for soil conservation. Weeping lovegrass 
is a bunchgrass readily used by cattle during the early growing period but, after it matures in June, its palatability drops precipitously. If previous year's growth is not removed prior to spring grazing, utilization is reduced. Prescribed burning in spring is the preferred method to remove previous year's growth, increase nutritive value, production, and utilization by cattle (Klett et al. 1971). Fertilization will also increase nutritive value and production of weeping lovegrass (McMurphy et al. 1975; Rocateli 2017). Given these characteristics, it has been recommended that it be burned prior to initiation of spring growth, fertilized with $100 \mathrm{~kg} \mathrm{~N} \mathrm{ha}^{-1}$, and stocked heavily before palatability decreases (Rocateli 2017).

Johnsongrass was introduced into the US from Turkey in the early 1800 s as a perennial forage crop. It is ubiquitous throughout much of the region, but has vigorous rhizomes and seed production such that it is listed as a noxious weed in several states. Other introduced warm-season perennial forage species occur within the region but are of limited local importance like kleingrass, wilman lovegrass, and dallisgrass.

Introduced annual warm-season grasses are best used on lands suited to cultivation and provide greater flexibility than perennial forages. These forages can be very productive and have high nutritive value. Sudangrass, sorghum $\times$ sudangrass hybrids, and forage sorghums, with adequate water and fertility, can produce large quantities of high-quality forage for grazing, hay, or silage. The yield potential under irrigation or in eastern Oklahoma is as high as $33 \mathrm{Mgha}^{-1}$. However, $330 \mathrm{~kg} \mathrm{Nha}^{-1}$ is needed to reach this level of production (Rocateli 2017). Pearlmillet is another common introduced warm-season forage used in the region.

Other warm-season annual forages include crabgrass and teff. Crabgrass is an aggressive annual that produces high-quality forage following wheat or other winter crops. This is not recommended in fields where crops that are not glyphosate tolerant may be grown as there are few postemergence herbicides available to control crabgrass (Warren et al. 2018). Crabgrass is used for grazing and hay and nutritive value remains high even as the crop reaches maturity (Ogden et al. 2005; Beck et al. 2007). Teff was introduced from east Africa and is a major cereal crop in Ethiopia. Teff seed is very small and the seed must not be placed too deeply in the soil. It germinates and establishes rather quickly and can be harvested $45-55$ days after planting. The crop is most commonly used for hay but can also be grazed. Teff tends to be shallow rooted, especially early in the growing season and may be pulled out of the ground when grazed. The crop is drought tolerant and the nutritive value of the forage is similar to many other warm-season annual forages (Twidwell et al. 2002; Anderson and Volesky 2012).

Prussic acid poisoning can be a concern for grazing young or new growth of forage sorghums especially in fall, after drought, or following crop injury. Nitrate accumulation can also occur, especially under poor growing conditions or, when excess $\mathrm{N}$ is applied.

\section{Native Grasses}

Additional information on many of the native warmseason grasses including the bluestems, panicgrasses, and other miscellaneous warm-season species can be found in Chapter 17.

Native plant species used for livestock forage in the temperate subhumid and semiarid region are typically found growing within a community of adapted species rather than in monoculture. The native species include a tremendous variety from all the functional forms (e.g. warm-season tall grasses, cool-season annual grasses, warm-season short grasses, trees, and forbs). Importance of each species for provisioning forage in a community varies with climate and soils across the region. Within a given community, most species are sub-dominants with often only three to five key species responsible for providing $80-90 \%$ of the forage produced. The east-west mean annual precipitation gradient and, to a lesser extent, the north-south mean annual temperature gradient that occur across the Great Plains, in large part, determine which forage species occupy the native plant communities, their proportions and total productivity. The communities common to the temperate subhumid and semiarid region have been grouped into several broad rangeland types including tallgrass prairie, northern and southern mixed prairies, and shortgrass steppe (Lauenroth et al. 1999). Productivity of these native plant communities ranges across the region from less than $1500 \mathrm{~kg} \mathrm{ha}^{-1}$ along the entire western edge to nearly $6000 \mathrm{~kg} \mathrm{ha}^{-1}$ along the southeastern edge of the region where water and heat units are most plentiful. Along the north-eastern edge of the region production is typically between 3000 and $4000 \mathrm{~kg} \mathrm{ha}^{-1}$ (Sala et al. 1988).

In the native tallgrass prairie, key forage species are warm-season tallgrasses such as big bluestem, switchgrass, indiangrass, and eastern gamagrass. Sand bluestem is an important tallgrass that is generally associated with sandy, loamy sand and sandy loam soils and with sandy regions such as the Nebraska Sand Hills. Of these species, eastern gamagrass begins growth earliest and big-bluestem is the latest. The tallgrasses are relatively tolerant of grazing, but eastern gamagrass, in part because it is extremely palatable, strongly preferred, and has high nutritive value, will decline and even disappear if continually grazed short. The forage value of the other tallgrass species is good, meeting the nutritional needs of most classes of livestock in spring and summer before stem elongation begins, but declines through the fall and by winter, forage quality is poor, lacking enough protein to meet the needs of grazing livestock.

In the shortgrass steppe, precipitation is insufficient in most years to support dense stands of tallgrasses and the 
dominant forages are warm-season short grasses including buffalograss and blue grama. These forages tend to be very tolerant of grazing and are palatable to all classes of livestock. The shortgrass steppe, while less productive than tallgrass prairie, produces forage composed mostly of leaf tissue with little stem tissue extending into the canopy. Therefore, the nutritive value of these forages is among the highest of the native forages, especially in the summer months. Blue grama and buffalograss will maintain good nutritive value with sufficient CP for many classes of livestock into the fall and winter months.

The northern and southern mixed-grass prairies are ecotones between the tallgrass prairie and the shortgrass steppe, and they contain species from both grassland types that contribute significantly to the forage of the mixedgrass prairie. The dominant forage species in the southern mixed-grass prairie, however, are warm-season mid-grasses such as little bluestem, sideoats grama, and curly mesquite, in the northern mixed-grass prairie, cool-season perennial grasses such as the wheatgrasses, needle-andthread, and green needlegrass are dominant. In the southern mixed-grass prairie, cool-season perennial grasses such as texas wintergrass, canada wildrye, and texas bluegrass are scattered across the prairie, and may provide important high-quality forage as a supplement to the senesced warm-season forages during the late winter months before the warm-season grasses begin spring growth.

Forbs contribute the greatest floristic diversity to plant communities of the Great Plains and this functional group contributes greatly to forage quality as these species are often low in fiber and quite digestible. Another functional class of species that provide important forage for livestock, especially small ruminants, are shrubs and trees. Increases in the burn frequency since European settlement of these semiarid and subhumid temperate regions have resulted in increased abundance of many woody species; however, many are undesirable, such as the many Juniperus spp. becoming more prevalent across the southern plains.

\section{Introduced, Invasive Species}

One of the primary concerns with introducing non-native or even native forages into non-traditional areas on range and pasture lands is their invasion potential. Smooth bromegrass, for example, is reported to be a common invader of disturbed sites throughout the Great Plains (Howard 1996) though this may be less of a concern in well-managed pastures and rangelands (Vogel and Hendrickson 2019). Grant et al. (2009) evaluated US Fish and Wildlife Refuges in North and South Dakota and found most of the vegetation (45-49\%) was comprised of smooth bromegrass, which the authors attributed to lack of disturbance. Also, in the northern portion of the region, crested wheatgrass has spread and is invading native rangelands (Henderson and Naeth 2005).
One of the major invasion threats in the northern part of the subhumid region is kentucky bluegrass. In the Northern Great Plains, kentucky bluegrass is present on more than $50 \%$ of the private acres sampled by the USDA-NRCS (Toledo et al. 2014). Although the original areas of concern with kentucky bluegrass invasion were in the subhumid portions of the temperate region, currently it is beginning to be a concern in the semiarid portion as well.

In the southern portions of the temperate region, old-world bluestems and sericea lespedeza are examples of invasive forage species of concern (Fulbright et al. 2013), while in the western or more semiarid part of the temperate region, annual bromegrasses, such as cheatgrass or Japanese brome, can be of major concern. Invasions of these annual bromegrasses often lead to an increase in wildfires further damaging native vegetation in the region (D'Antonio and Vitousek 1992). Though wildfires can be damaging, prescribed fire at the right time is an important control mechanism for woody invasive species such as juniper and mesquite (Wright 1988).

There are multiple concerns with invasive species. Invasive species can alter nitrogen $(\mathrm{N})$ cycling and reduce carbon storage (Wedin and Tilman 1996), lower plant diversity (Henderson and Naeth 2005), and impact wildlife habitat and soil microbial diversity (Fulbright et al. 2013). Some invasive species, such as kentucky bluegrass, can alter forage distribution by shortening the grazing season rather than lengthening it. Because of these concerns, assessing invasion potential needs to be a high priority when designing forage systems for temperate regions.

\section{Forage Systems}

Harvest strategies for both grazed and conserved forages involve compromises and are dependent on climate, forage species, kind and class of grazing livestock, and the management skills of the producer. Forage of young plants is higher in nutritive value than that of more mature plants. This is because the cells of young plants are biochemically active, capturing and storing energy, synthesizing proteins and fats, and so on, while cells of older plants are low in biochemical activity (Huston and Pinchak 1991). Thus, for grazing and depending on the nutrient requirements of the target animal, it is often important to use some sort of grazing management strategy to provide forage of acceptable nutritive value for younger, growing animals or for lactating females. Hay harvest schedules are heavily dependent on weather conditions and, in many instances, hay is harvested at too mature a stage to meet the needs of animals with high-nutrient requirements. Prine and Burton (1956) and Knox et al. (1958) demonstrated the adverse effect on crude protein and the increasing levels of lignin in bermudagrass harvested at various stages of maturity. 
Crude protein was reduced by nearly half and lignin concentration rose to $12 \%$ of the dry matter in bermudagrass cut at two-week intervals vs eight-weeks intervals. All forage species followed similar trends, although the effect was not as pronounced for cool-season grasses or legumes. Therefore, it is important that forages to be conserved as hay be harvested to optimize both quantity and nutritive value of the crop.

Many times, however, hay supplies are limited or nonexistent, hay is of low nutritive value, or forage may be in short supply due to drought and livestock must be supplemented. Two types of protein supplements are commonly used under these circumstances: (i) non-protein $\mathrm{N}$ sources (urea, biuret) and (ii) high-protein feeds such as alfalfa hay, cottonseed meal, or soybean meal (Holechek et al. 1998). Cottonseed meal is probably the most widely used supplement in the temperate subhumid and temperate semiarid regions. It typically contains $40-45 \%$ crude protein, thus only requiring approximately $0.5-0.9 \mathrm{kghead}^{-1} \mathrm{~d}^{-1}$ for cows and $0.1-0.2 \mathrm{~kg} \mathrm{head}^{-1} \mathrm{~d}^{-1}$ for ewes (Holechek et al. 1998).

Energy supplementation may also be required at times during the year due to drought or heavy snow. Barley and cracked corn are two of the more common energy supplements used under range conditions in the temperate subhumid and temperate semiarid regions. These feeds usually depress forage intake and serve as a substitute for range forage (Holechek et al. 1998). Alfalfa hay can also be used as an energy source and is particularly important when crude protein is also limiting. Holechek et al. (1998) suggested that due to the low cost per cow, mineral supplementation should be provided year-round by ranchers, rather than just during fall and winter when animals might be deficient in phosphorus.

Using corn residue is an important source of forage especially in the central and northern Corn Belt (Schmer et al. 2017). Redfearn et al. (2019) estimated the added economic value to the crop sector of grazing crop residues in Kansas, Nebraska and the Dakotas at $\$ 95$ million. Grazing crop residues usually removes less than $40 \%$ of the total residue, which is important for soil conservation (Lorenz 1977), but grazing crop residues during spring may adversely affect water infiltration and soil bulk density (Rasby et al. 1998). A review by Rakkar and Blanco-Canqui (2018) suggested that grazing crop residues generally had a positive impact on soil nutrients and while it may increase some soil compaction parameters, residue grazing had little impact on crop yield. The composition of the crop residue (i.e. grain, leaf, or stalk), whether it was irrigated, and the days after harvest are all factors determining the nutritive value or crop residues (Rasby et al. 1998).

In addition to crop residues, many producers rely on winter range for forage during the winter months (Jordan et al. 2002). Grazed winter forages, however, may not meet the protein requirement of cows (Lardy et al. 1999; Jordan et al. 2002). Lardy et al. (1999) concluded that degradable intake protein was the first limiting nutrient before energy and undegradable intake protein for summer calving cows on autumn-winter range in the Nebraska Sandhills. Larson et al. (2009) found that cows grazing corn stalk residue produced calves with a greater birth and weaning weight than did cows grazing winter range. An inexpensive source of degradable intake protein may be the only requirement to maintain cows on low-quality winter forage (Jordan et al. 2002). Calf weaning weight was increased with using a $28 \%$ protein cube as a supplement (Larson et al. 2009). Switching degraded ranges from summer to winter use is a proven method of improving range condition in the Nebraska Sandhills, but the impact of dormant-season grazing on the vegetation has not been quantified.

\section{Rangelands Only}

Forage systems that almost exclusively utilize rangelands occur across much of the Great Plains are becoming increasingly important to the west, where other land uses are less common. These systems are also used in the southern Great Plains, where winters are less severe and standing dead forage is not snow-covered for extended periods of time. This system is also common in the Kansas Flint Hills and the Osage region of Oklahoma where soil conditions, rather than climate, limit other land use options. In general, rangelands are extensively managed with low inputs and use proper grazing management and prescribed fire as the two most important management practices. Other management practices such as fertilization, reseeding, or harvesting hay are generally impractical or uneconomical on rangelands. An exception to this is the annual harvesting of native grass hay from productive, yet fragile, wet meadows in the Nebraska Sandhills.

Rangelands provide grazing animals with a variety of plant species from which to select their diet; from low-nutritive value standing dead grass, moderatenutritive value matured current year's growth, to the high-nutritive value young grass leaves and forbs. Thus, diet selection is dynamic resulting from changes in palatability among species available. Animals grazing these rangelands have different plant preferences and some animal species better match the vegetation in an environment than another species. Diet selection in these systems generally results in better diet quality than the composite quality of the forage on offer. Because all possible bites are not equal in value, increasing stocking rates can cause competition for high-quality bites reducing an animal's ability to select a quality diet and potentially reducing performance.

The objective of these systems is to harvest a diet that meets the nutritional needs of the grazing animals. These forage systems are composed of native vegetation, susceptible to degradation, and difficult to restore. If 
grazing is to be sustained, the forage use must be balanced with the need to maintain or improve the existing native plant community. This is accomplished by managing the vegetation to promote growth and persistence of desired plant species and suppressing the invasion and spread of undesirable plant species. Great Plains plant communities developed with both grazing and fire, burning every 2-20 years depending on the region (Guyette et al. 2012). These periodic fires kept woody species suppressed or relegated to fire protected sites, such as along steep escarpments, in canyons, and along rivers. Fire still plays an important role in keeping many undesirable species from spreading into rangelands although herbicides and mechanical practices have also been used. Hay fed on rangelands can be a vector for invasive weeds. The invasion risk depends on species being fed; for example, an introduced annual like sorghum-sudangrass is much less likely to escape into rangelands than old-world bluestem.

The most important grazing management decision in this system is managing the stocking rate and then providing a rotation for different timing of use for growing-season rest. The proper stocking rate is related to the quantity of forage produced each year. Rangeland productivity is related to site potential (defined by soil characteristics), the ecologic state or phase (which plant species occupy the site and in what proportion), previous year's weather (e.g., the bud bank), and current year's weather (e.g. the amount and timing of heat units and available water). Initially stocking rates should be set in relation to the proportion of different ecologic sites within a grazing unit, the state or phase in which the sites are found, objectives for livestock performance, patterns of land use (e.g. incomplete accessibility due to slope or distance from water), expected effects on the vegetation, and anticipated weather (e.g. expected annual precipitation). Median annual precipitation may be a more appropriate expectation for setting stocking rates than the mean in some areas. Median annual precipitation describes the amount of precipitation expected in half the years and does not give undo credit to exceptionally wet years that contribute little to the production in other years. The difference between mean and median precipitation is typically greater in dryer climates. Experience and changing management objectives are used in subsequent years to modify stocking rates. Stocking rates may also be adjusted, depending on when the grazing will occur and whether plants are susceptible to injury from grazing at that time. For example, a greater proportion of the annual production may be harvested if a good portion of the use will occur in the dormant season than if the grazing will all be done in the growing season.

In general, semiarid and subhumid temperate rangelands can be sustainably grazed using $40-50 \%$ of the key forage species produced each year (Holechek 1988). The rule of thumb of "take half, leave half" is generally adequate, but can be misapplied. When livestock graze, they "take" forage by consumption (i.e. direct intake), but also by trampling and fouling. Another source of "take" that should be considered is use by wildlife or damage by insects. The annual forage supply should be multiplied by an appropriate harvest efficiency factor to determine actual forage available for livestock consumption and $30 \%$ is a good initial value for this factor. At 30\% harvest efficiency, $50 \%$ total use is achieved when $60 \%$ of all the forage used is consumed by livestock with the remaining $40 \%$ of use due to trampling, fouling, wildlife, and damage from pests. Grazing efficiency is used to describe the amount of forage that is consumed directly as a proportion of all the forage use $(60 \%$ in the preceding example).

Grazing systems that utilize rangelands exclusively can be grouped into two categories; (i) breeding animal systems where mature animals graze the rangelands continually with their offspring from birth until weaning and (ii) growing animal systems where the growing animals graze the rangeland during periods when the nutritive value of the forage can support animal growth. In the breeding animal system, nutritional requirements change during the production cycle and are lowest after weaning and greatest during the first several months postpartum which can be aligned with changing nutritional value in the forage to minimize the need for nutritional supplements. On many rangelands, the winter months are protein deficient and a protein supplement is typically offered to meet the animal's maintenance requirement. This supplementation practice requires that the rangeland has enough low-quality forage available that energy will not become a limitation. In these systems, forage may become unavailable due to inclement weather and a supply of good-quality hay is typically used to supplement energy during these times. During the growing season, nutritive value is sufficient to support the greater nutritional needs of maintenance and lactation and no supplemental protein or energy is offered during this period. The most common of these systems is the cow-calf system, but in regions such as in the Edwards Plateau of Texas, where shrubs and forbs have a greater role in the plant communities, systems with sheep and goats are more common.

The growing animal systems are not year-round systems, rather they target the rangeland use to periods when the forage has the greatest quality. A fairly traditional system of this type would be the season-long stocking (SLS) system where light-weight stocker cattle graze the rangelands between late April and the first of October. In some regions, notably the Kansas Flint Hills and Osage region of Oklahoma, the SLS system has been replaced with other systems to better mitigate the declining forage quality as the season progresses. In regions where high-nutritive value is maintained in the forage throughout the growing season the SLS system is preferred. The 
first effort to replace the SLS system was an intensive early stocking (IES) system, where the period of use is shortened by half, and stock density is doubled, from the traditional SLS system. In the IES system, animal performance declines slightly but the small reduction in animal performance is more than compensated with the increased gains per hectare. Because the IES system kept the forage short and of high quality, researchers considered a next step in the evolution by adding a period a late-season grazing (LSG), where stock density was cut in half and the remaining cattle continued to graze until the first of October. To keep from over-grazing these ranges, the IES-LSG is followed in the next year by IES without LSG (the IES-LSG/IES rotation). In the tallgrass prairie where annual burning is acceptable, any of these stocker systems can be further improved by incorporating an annual fire before grazing begins. For tallgrasses, the best time to burn is just before the warm-season grasses green-up.

\section{Introduced Forages Only}

Depending on the north-south location in the temperate subhumid region, introduced-only forage systems may be based on either warm-season or cool-season perennial grass and often include both types. Introduced forages have been used in livestock production systems because of their grazing tolerance and response to fertilizer. Proper management begins with the selection of adapted species that are persistent and will produce acceptable dry matter yields of the desired nutritive value to meet the needs of the grazing livestock (Cherney and Allen 1995). Introduced forages in the temperate subhumid region generally respond well to fertilization if (i) pastures are irrigated or receive $>625 \mathrm{~mm}$ average annual precipitation, (ii) hay meadows have equivalent soil moisture availability, or (iii) pastures or hay meadows are naturally sub-irrigated (Vallentine 1989).

In the temperate semiarid region, introduced forages must either have excellent adaptation to heat and drought (i.e. crested wheatgrass) or be irrigated. Vallentine (1989) noted that introduced cool-season perennial grasses responded better to $(\mathrm{N})$ fertilization than did native cool-season grasses. While bermudagrass and old-world bluestem generally exhibit the best response to (N) fertilization, Vallentine (1989) also stated that the warm-season native tallgrasses and midgrasses such as the lovegrasses, switchgrass, bluestems, indiangrass, and sideoats grama responded more favorably to $(\mathrm{N})$ than the shortgrasses such as blue grama and buffalograss. As in the more mesic areas of the United States, any supplemental fertilizer should be used with caution.

Bermudagrass and the old-world bluestems serve as the warm-season pasture base throughout Texas, Oklahoma, and Kansas. These warm-season perennial grass-based systems are generally stocked with cattle, sheep, or goats year-round with excess forage harvested as hay for winter feeding and supplemented with other purchased supplemental feedstuffs, as needed. Some producers, however, overseed the warm-season grass pastures with cool-season annuals to provide longer grazing seasons, improved pasture nutritive value, and reduced costs associated with winter feeding. Coffey and Moyer (1991) found that stocker cattle grazing cereal rye no-till drilled into bermudagrass sod, offered the potential for extending the grazing season and providing for more total cattle production than from bermudagrass alone. Volesky et al. (1996), likewise, evaluated interseeding rose clover and hairy vetch and noted that interseeding stands of old-world bluestem could reduce $\mathrm{N}$ fertilizer input, extend the grazing season, and enhance diet quality.

Further north in the temperate subhumid region, cool-season perennial grasses dominate introduced forage pasture systems. From Kansas north, smooth bromegrass pastures are used extensively. In a three-year study at Mandan, North Dakota, steer average daily gains from 'Lincoln' smooth bromegrass averaged $1.04 \mathrm{~kg} \mathrm{~d}^{-1}$, which was greater than steers grazing native range $\left(0.98 \mathrm{~kg} \mathrm{~d}^{-1}\right)$ or crested wheatgrass $\left(0.97 \mathrm{~kg} \mathrm{~d}^{-1}\right)$ (Karn and Ries 2002). Other cool-season perennial species, such as the introduced wheatgrasses and orchardgrass, also provide pastures for grazing livestock. In Oklahoma (Reuter and Horn 1999), animal average daily gains were approximately $1 \mathrm{~kg} \mathrm{~d}^{-1}$ for 'Manska' pubescent wheatgrass, 'Paiute' orchardgrass, and 'Lincoln' smooth bromegrass for 56 days with beef gains of $116 \mathrm{~kg} \mathrm{ha}^{-1}$.

Though winter wheat throughout the United States is typically planted with grain harvest in mind, the crop is used extensively as a dual-purpose (grain + grazing) crop in much of the temperate subhumid region. Shelton (1888) was one of the first to report on the advantages of the dual-purpose use of wheat. Later, in their review of wheat grazing, Redmon et al. (1995) reported from $75 \%$ to $90 \%$ of the irrigated winter wheat in Texas was managed for cattle grazing and that $65 \%$ of the winter wheat planted in Kansas was used for fall and spring grazing. In Oklahoma, it is commonly reported that 50\% or more of the winter wheat hectarage is grazed.

\section{Complementary Livestock Systems}

The word complementary means "serving to fill out or complete" or "mutually supplying each other's lack" (Merriam-Webster 1990). In the case of complementary forage systems, the term can have two similar but slightly different meanings. In more arid areas, complementary forage systems refer to the blending of both rangeland and introduced forages to provide a system that more fully meets the nutrient requirements of the grazing livestock, and thus more fully meets the manager's production goals. However, in more subhumid systems, complementary forage systems are systems that use forages with different seasons of growth, such as cool- and warm-season grasses 
sequentially to improve seasonal productivity (Moore et al. 2004).

In the Northern Great Plains, rangeland is the primary source of forage (Lorenz 1977) but the morphologic development of native grasses often requires using introduced forages in the spring and fall to complement the native range. In North Dakota, for example, weather often permits grazing in late April or early May. Delaying turnout by 30 days to late May or early June has been shown to increase production on native rangeland by 35\% (Lorenz 1976). However, forage gaps are created in the early spring as well as the late summer or early fall when native grasses have senesced. Complementary forage systems combine different types of forages to fill these production and nutritional gaps. Including introduced grasses with native rangeland can "complement" or extend the grazing season on rangelands (Lorenz 1977). Mcllvain (1976) noted the philosophy of complementing low-producing, rough grasslands with high-producing tame pastures opened the door to (i) fitting green forages into dry periods, (ii) opportunity grazing or resting of each forage resource for its proper development and use, (iii) avoidance of grazing during periods when poisonous plants were highly hazardous, (iv) use of flushing pastures, (v) use of breeding pastures, (vi) use of day-night rotation, (vii) use of dehydrated forages for concentrates, and (viii) use of high-quality feed as green creeps for calves or steers needing a rapid gain, and following them with cows or younger steers to clean up graze.

Derner and Hart (2010) found yearling Hereford heifers had two to four times the gain on crested wheatgrass or russian wildrye compared to shortgrass native range indicating these forages could fill forage gaps. The optimal ratio of crested wheatgrass pasture to native rangeland was determined to be $1: 3.9$ when estimated yields, costs and prices were considered (Hart et al. 1988). The use of complementary forages can double the carrying capacity for stockers and beef cows (Launchbaugh et al. 1978). Sims (1993) reported that a complementary grazing system using double-cropped winter wheat and annual forages reduced land requirements by $40 \%$ in Oklahoma. Therefore, a complementary forage system in either the temperate subhumid or temperate semiarid regions would offer multiple advantages to livestock producers.

\section{Integrated Crop-Livestock Systems}

Integrated crop-livestock systems have been proposed as a method to achieve agricultural sustainability while still maintaining productivity (Franzluebbers 2007; Martins et al. 2016). Research suggests that incorporating livestock into cropping systems has minimal negative impact and may actually increase subsequent crop production. However, there is less information on livestock performance in integrated systems or if there are differences among livestock breeds in their performance in integrated systems. Calves from cows grazing crop residues in winter had heavier birth and weaning weights than calves from cows grazing winter range only (Larson et al. 2009). As with most grazing systems, heavier stocking rates decreased individual cow body weight, but increased stocking rate did not seem to affect subsequent crop yield (Stalker et al. 2015). Even less is known about the performance of individual breeds within integrated crop-livestock systems. A study from Brazil found that $1 / 2$ Angus by $1 / 2$ Nellore steers performed better in integrated crop/livestock systems than did $1 / 2$ Charolais by $1 / 4$ Angus and $1 / 4$ Nellore steers (Costa et al. 2017).

Incorporating forages into integrated crop-livestock systems provides new opportunities and challenges. Forages can be important aspects of these systems and provide a yield boost to subsequent crop production. In the semiarid temperate region, Franco et al. (2018) found that unfertilized spring wheat yields, following two years of alfalfa, were similar to fertilized continuous no-till spring wheat yields and that yield effects from three years of alfalfa in the crop rotation could last up to three years following stand termination. The same study indicated that a cool-season grass-alfalfa mixture could not only provide the yield benefits but enhance selected soil quality attributes more than alfalfa alone (Liebig et al. 2018).

Cover crops are often a critical part of integrated systems because producers are attracted to their soil health attributes but need livestock to increase the economic feasibility of using them. Since most cover crops are annuals, cover crop species can be adjusted yearly to address specific soil quality and animal performance objectives. In a semiarid portion of the Northern Great Plains, Sanderson et al. (2018) found that spring-planted cover crop mixtures yielded more, on average, than monocultures but produced less than the most productive monocultures. However, the same study found that late-season planted cover crops, produced little forage because of dry soil and erratic weather conditions. However, in South Dakota, legume cover crops planted in mid- to late-August following winter wheat harvest did show forage potential with crude protein concentrations ranging from 113 to $270 \mathrm{~g} \mathrm{~kg}^{-1}$ on yields ranging from 933 to $4590 \mathrm{~kg} \mathrm{ha}^{-1}$ (Hansen et al. 2015).

\section{Challenges for Future Forage Systems}

\section{Land Use}

\section{Southern Plains}

During settlement of the southern plains, the typical family farm was far smaller than today and was generally diversified with both crop and livestock production. Farm mechanization and the resulting expansion in cultivated area occurred around the time much of the Great Plains entered a period of major drought. The drought resulted in poor crop establishment, vast areas of unprotected soil, 
and ultimately to significant soil losses by wind which earned parts of the region the moniker of "Dust Bowl" and this period is often referred to as the Dust Bowl Era. The period continues to shape land use in much of the southern Great Plains. Many of the lands broken out for cultivation were not well suited to the practice. These lands were productive during the initial years of cultivation because the soils still contained abundant organic matter and precipitation was above normal for the region. There was a belief, at this time, that "rain follows the plow".

Now, the land that remains in cultivation for crop production is primarily irrigated land and conservation tillage or no-till are the common tillage practices. Other lands have either naturally reverted back to mostly native species (commonly referred to in the region as "go-back land"), have been planted to a perennial forage crop such as bermudagrass or old-world bluestem, or the lands have been enrolled in the Conservation Reserve Program (CRP) and have been seeded to primarily perennial grasses. The CRP lands are not grazed or hayed unless allowed by emergency declaration. Over one quarter of all CRP acres enrolled in the US at the end of 2018 were in the southern plains states of Texas, Oklahoma, Kansas, and New Mexico.

Taylor et al. (2015), reported land used for hay and pasture was included in the agriculture class, but rangelands and CRP were included together in the grassland/shrubland class. Nonetheless, it is instructive that in recent years Great Plains land use changes predominately involved exchanges between the two largest land use classes, namely agriculture and grassland/shrubland. In the entire Great Plains, agriculture was the dominant land use at $46.4 \%$ and grassland/shrubland was a close second at $42.7 \%$ to $42.1 \%$ between 1973 and 1986 . By 1992 , the two classes were tied at $44.2 \%$ and by 2000 , grassland/shrubland was the dominant land use at $44.4 \%$ while agriculture had dropped to $43.8 \%$.

Some regions within the southern Great Plains experienced little to no change in land use such as the Edward Plateau in south-central Texas, the central Oklahoma/Texas Plains, and the Flint Hills of Kansas. Soil limitations in these areas hindered agricultural development during settlement and these lands are well suited to their current use. Other regions in the Southern Great Plains experienced great changes. For example, in the east central Texas plains about $3.8 \%$ of agricultural land was converted to the grassland/shrubland class between 1973 and 2000 and $1.7 \%$ of forest land was converted to agricultural land. The three greatest net changes between 1973 and 2000 in the east central Texas plains was the $3.7 \%$ increase in the grassland/shrubland class and the $2.7 \%$ and $1.8 \%$ losses in agricultural land and forestland, respectively. The western high plains experienced large net changes in almost exclusively the grassland/shrubland and agriculture land uses. Grassland/shrubland had a net increase of $5.7 \%$ and agriculture had a $5.8 \%$ net decrease. Most of these changes occurred between 1986 and 1992 when the CRP was implemented. The central Great Plains experienced agricultural land-use increases between 1973 and 1986 (primarily through conversion of grassland/shrubland), but this expansion was later reversed between 1986 and 1992 so that net land-use change over the 27-year study was relatively small with a net decrease in agricultural land and grassland/shrubland of $0.6 \%$ and $0.1 \%$, respectively, and a $0.7 \%$ increase in developed land over this period with growth of cities like Oklahoma City, Wichita, KS, and Abilene, TX. The Texas Blackland Prairies ecoregion, which is home to parts of the Dallas-Fort Worth metroplex, Austin, and San Antonio has experienced rather large net land-use changes related to urban growth between 1973 and 2000. Agricultural lands and forests have had net losses of $5.6 \%$ and $0.2 \%$, respectively, while developed land and grassland/shrubland have increased $3.8 \%$ and $0.9 \%$ respectively.

\section{Northern Plains}

One of the biggest challenges to forage and rangelands in the northern part of the subhumid and semiarid temperate region is the changes in land use that have occurred. Between 2006 and 2011, rates of conversion from grassland to corn/soybean cropland in the subhumid temperate region were $1-5.4 \%$ which is similar to deforestation rates in Brazil, Malaysia, and Indonesia (Wright and Wimberly 2013). Though there is some controversy about the Wright and Wimberly methodology (Laingen 2015) and interpretation of these changes (Kline et al. 2013), anecdotal accounts suggest that changes in land use are occurring, especially in more subhumid areas east of the Missouri river. Some estimates are about 203000 ha of native prairie was converted to cropland in the Dakotas and Montana between 2002 and 2007 (Fargione et al. 2009).

Land conversion to and from cropland occurs continuously, but a major surge in land conversion was relatively recent. A rapid increase in crop prices between 2006 and 2009 resulted in a $64 \%$ gain in typical farm profitability (Swinton et al. 2011). The improved profitability increased pressure to find more land to farm. Between 2008 and 2012, most (77\%) of the new cropland came from grassland (Lark et al. 2015), resulting in 2.3 million hectares of grassland being converted to cropland. While most land conversion has occurred in the Dakotas, the presence of biorefineries has resulted in cropland expansion in the temperate subhumid areas in Minnesota and Wisconsin (Wright et al. 2017).

Besides the price increase, increased precipitation, a longer growing season (DeKeyser et al. 2013), technological improvements such as irrigation, and 
precision agriculture have provided the means to increase cropland acreage (Stubbs 2015) or improve profits (Scharf et al. 2011). Technology has also reduced the management intensity needed in agricultural systems (Hendrickson et al. 2008a, 2008b) making it easier to operate larger acreages. Average farm size ranges from 209 acres in Wisconsin to 349 acres in Minnesota to 1268 acres in North Dakota (USDA-NASS 2014). The combination of improved profits, favorable climate, and technological advances provided an environment for changes in land use.

\section{Land Fragmentation and Managing Small Units Sustainably}

The 2012 census of agriculture shows significant increases in the number of farms in the counties surrounding major Texas urban centers including the Dallas-Fort Worth metroplex, Austin, San Antonio, and Houston. Around these large urban centers, agricultural land and forest is being lost to increases in developed land and grassland/shrubland. A significant number of people employed in these cities have purchased small acreage farms in nearby rural areas within commuting distance of their place of work. Some farms may be farther out from their work than is reasonable for a daily commute but can be easily visited on weekends.

The land is typically not cultivated and is used for keeping animals and forage production. This trend has resulted in land fragmentation and often the main objective of these small farms is not to make a profit but to provide the owners with a rural lifestyle and a place to keep livestock. The uncoupling of profits from the management of these small farms could promote grazing land improvement, but often, the forage demand of the animals kept will exceed the forage produced on these small farms and the deficit is supplemented with purchased feed and hay. Thus, many of these grazinglands are seldom rested, are over grazed, and a repository for imported nutrients.

\section{Climate Change}

\section{Drought}

Drought is a normal feature of a given climate that occurs when the precipitation received for a period is significantly less than normal. When the climate is stationary, these periods are necessarily offset by pluvial periods - periods with significantly more precipitation than normal. The Great Plains has had a very long history of alternating between drought and pluvial periods on an approximately decadal scale. Some of these periods stand out for the magnitude or duration of the deviation. Some historical examples of the decadal cycle oscillations include the droughts of the 1930s, 1950s, and 2010s with the more pluvial periods of the 1940s and the 1970s and 1980s. Proxy climate records, such as from tree-ring, lake sediment or dunal paleosol data, indicate these decadal drought cycles have persisted in the Great Plains for several hundred years and there is also evidence of century-scale mega-droughts such as those in the fourteenth, fifteenth, and sixteenth centuries. The decadal cycles seem to be modestly related to pan-Pacific sea surface temperature variation which explains about one-third of the variation in low-frequency precipitation (timescales longer than about six years) (Schubert et al. 2004).

Drought, especially widespread drought, has a significant effect on forage-based agriculture. The 2011 drought in the southern Great Plains was the worst single-year drought in the historical record for much of the southern Great Plains and the destocking that followed contributed to US beef cattle inventories reaching their lowest numbers since the 1950s. Drought not only impacts forage production and quality, but in regions that depend on earthen ponds for water may also impact accessibility to forage resources due to a lack of drinking water.

Future concern about drought has components of the natural variability in the historical and proxy records. Many climatologists are now predicting that we may be entering a period of climate change that may result in a shift in the central tendencies for precipitation around which decadal and longer-scale variation has persisted. While there appears to be consensus that much of the interior US is likely to see $1-2{ }^{\circ} \mathrm{C}$ warming over the next 40 years, predictions of changes in precipitation are more uncertain and growing season uncertainties are probably larger than dormant season uncertainty even with a $5 \%$ decrease in precipitation predicted for the south central US (Walthall et al. 2012).

\section{Extreme Wetness}

Rather than drought, some areas have experienced extreme wetness. Weather data from the Northern Great Plains Research Laboratory (USDA-ARS) located in Mandan, North Dakota showed that for a 75-year period (1916-1990), the average annual precipitation was $38.1 \mathrm{~cm}$ (High Plains Climate Center 2019). However, between 1991 and 2000, average annual precipitation increased $25 \%$ to $50.8 \mathrm{~cm}$. The periods of 2001-2009 and 2011-2016 also had greater than average precipitation (44.4 and $47.6 \mathrm{~cm} \mathrm{yr}^{-1}$, respectively).

The increased precipitation did impact forages and grasslands. Several studies have documented an increase in kentucky bluegrass on rangelands between 1984 and 2004 (DeKeyser et al. 2015), a time that corresponds with the increased precipitation. Forage species grow now and are productive in areas previously considered too dry. The increase in precipitation may also mean that suggested stocking rates are too low for the current conditions. Producers need to be aware of, and react to, the increase in precipitation. 


\section{Summary}

The goal of forage systems is for grazing animals to receive most, if not all, of their nutrition from forages that are standing in the pasture. The high cost of feeding hay and other supplements is the economic driver behind this goal. Because of potentially severe environmental constraints in the temperate subhumid and temperate semiarid regions associated with drought and limited growing seasons, the availability of emergency feedstuffs will also be required for contingency livestock feeding programs. Hay feeding and the use of supplements, however, should be considered tactical solutions to short-term problems such as drought or ice and/or snow-cover days. Supplementation should generally only be used for specific production goals such as heifer development, backgrounding stocker cattle, or when forage is in short supply.

The forage systems used in the sub-humid and semi-arid temperate regions are diverse and dynamic. Regional extremes of geography and annual weather extremes require producers to be adaptable. Some common examples of such adaptations include cover crop grazing, complementing rangeland with introduced grasses and alternative grazing systems. Producers should evaluate the potential for complementary use of warmand cool-season forages, both native and introduced, to minimize production risks and improve potential net return of their livestock production systems. Development and utilization of a forage system should be a priority goal for all livestock producers.

\section{References}

Alderson, J. and Sharp, W.C. (1994). Grass Varieties in the United States. Agriculture Handbook No. 170. Washington, D.C.: Soil Conservation Service, United States Department of Agriculture.

Asay, K.H. and Jensen, K.B. (1996). Wheatgrasses. In: Cool-Season Forage Grasses (eds. L.E. Moser, D.R. Buxton and M.D. Casler), 691-724. Madison, WI: ASA, CSSA, and SSSA.

Bavendick, F.J. (1974). The climate of North Dakota. In: Climates of the States: Volume II-Western States Including Alaska and Hawaii (ed. Officials of the U.S. Department of Commerce), 811-825. Port Washington, NY: Water Information Center, Inc.

Beck, P.A., Hutchison, S., Stewart, C.B. et al. (2007). Effect of crabgrass (Digitaria ciliaris) hay harvest interval on forage quality and performance of growing calves fed mixed diets. J. Anim. Sci. 85: 527-535. https://doi .org/10.2527/jas.2006-358.

Biligetu, B. and Coulman, B. (2010). Quantifying the regrowth characteristics of three bromegrass (Bromus) species in response to defoliation at different development stages. Grassland Sci. 56: 168-176.

Bittman, S. and McCartney, D.H. (1994). Evaluating alfalfa cultivars and germplasms for pastures using the mob-grazing technique. Can. J. Plant. Sci. 74: 109-114.

Blayney, D.P. (2002). The Changing Landscape of US Milk Production. USDA SB978.

Boe, A. and Delaney, R.H. (1996). Creeping and meadow foxtail. In: Cool-Season Forage Grasses (eds. L.E. Moser, D.R. Buxton and M.D. Casler), 749-763. Madison, WI: ASA, CSSA, and SSSA.

Brady, N.C. and Weil, R.R. (1999). The Nature and Properties of Soils, 12e. Upper Saddle River, NJ: Prentice-Hall, Inc.

Bush, T., Ogle, D., St. John, L. et al. (eds.) (2012. Ed. (rev) St. John). Plant Guide for Orchardgrass (Dactylis glomerata). Aberdeen, Idaho: USDA-Natural Resources Conservation Service, Aberdeen Plant Materials Center 83210.

Cherney, J.H. and Allen, V.G. (1995). Forages in a livestock system. In: Forages, Volume I. An Introduction to Grassland Agriculture, 5e (eds. R.F Barnes, D.A. Miller and C.J. Nelson), 175-188. Ames, IA: Iowa State University Press.

Coffey, K.P. and Moyer, J.L. (1991). Performance and forage intake by stocker cattle grazing rye in monoculture or no-till drilled into bermudagrass sod. Kansas State University. Agricultural Research, Report of Progress No. 628.

Costa, P.M., Barbosa, F.A., Alvarenga, R.C. et al. (2017). Performance of crossbred steers post-weaned in an integrated crop-livestock system and finished in a feedlot. Pesq. Agropec. Bras. 52: 355-365.

D’Antonio, C.M. and Vitousek, P.M. (1992). Biological invasions by exotic grasses, the grass/fire cycle, and global change. Annu. Rev. Ecol. Syst. 23: 63-87.

DeKeyser, E.S., Meehan, M., Clambey, G., and Krabbenhoft, K. (2013). Cool season invasive grasses in Northern Great Plains natural areas. Nat. Areas J. 33: 81-90.

DeKeyser, E.S., Dennhardt, L.A., and Hendrickson, J. (2015). Kentucky bluegrass (Poa pratensis) invasion in the Northern Great Plains: a story of rapid dominance in an endangered ecosystem. Invasive Plant Sci. Manage. 8: 255-261.

Derner, J.D. and Hart, R.H. (2010). Livestock responses to complementary forages in shortgrass steppe. Great Plains Res. 20: 223-228.

Fargione, J.E., Cooper, T.R., Flaspohler, D.J. et al. (2009). Bioenergy and wildlife: threats and opportunities for grassland conservation. BioScience 59 (9): 767-777.

Foth, H.D. (1984). Fundamentals of Soil Science, 7e. New York, NY: Wiley.

Franco, J.G., Duke, S.E., Hendrickson, J.R. et al. (2018). Spring wheat yields following perennial forages in a semiarid no-till cropping system. Agron. J. 110: 1-9.

Franzluebbers, A.J. (2007). Integrated crop-livestock systems in the southeastern USA. Agron. J. 99: 361. 
Fulbright, T.E., Hickman, K.R., and Hewitt, D.G. (2013). Exotic grass invasion and wildlife abundance and diversity, South-Central United States. Wildl. Soc. Bull. 37: 503-509.

Funderburg, E.R., Biermacher, J.T., Moffet, C.A. et al. (2011). Effects of applying (N) on yield of introduced perennial summer grass cultivars in Oklahoma. Forage and Grazinglands 9 https://doi.org/10.1094/FG2011-1223-01-RS.

Funderburg, E., Biermacher, J.T., Moffet, C.A. et al. (2012). Effects of applying five (N) rates on quality of nine varieties of introduced perennial forages. Forage Grazinglands 10 https://doi.org/10.1094/FG2012-0517A-01-RS.

Grant, T.A., Flanders-Wanner, B., Shaffer, T.L. et al. (2009). An emerging crisis across northern prairie refuges: prevalence of invasive plants and a plan for adaptive management. Ecol. Restor. 27: 58-65.

Guyette, R.P., Stambaugh, M.C., Dey, D.C., and Muzika, R.M. (2012). Predicting fire frequency with chemistry and climate. Ecosystems 15: 322-335. https://doi.org/ 10.1007/s10021-011-9512-0.

Hansen, M.J., Owens, V.N., Beck, D., and Sexton, P. (2015). Suitability of legume cover crop mixtures in Central South Dakota for late-season forage. Crop, Forage \& Turfgrass Management 1 (1): 1-7.

Hart, R.H., Waggoner, J.W. Jr., Dunn, T.G. et al. (1988). Optimal stocking rate for cow-calf enterprises on native range and complementary improved pastures. J. Range Manage. 41: 435-441.

Henderson, D.C. and Naeth, M.A. (2005). Multi-scale impacts of crested wheatgrass invasion in mixed-grass prairie. Biol. Invasions 7: 639-650.

Hendrickson, J.R. and Berdahl, J.D. (2003). Survival of 16 alfalfa populations space planted into a grassland. $J$. Range Manage. 56: 260-265.

Hendrickson, J.R., Berdahl, J.D., Leibig, M.A., and Karn, J.F. (2005). Tiller persistence of eight intermediate wheatgrass entries grazed at three morphological stages. Agron. J. 97: 1390-1395.

Hendrickson, J.R., Hanson, J.D., Tanaka, D.L., and Sassenrath, G. (2008a). Principles of integrated agricultural systems: introduction to processes and definition. Renewable Agric. Food Syst. 23: 265-271.

Hendrickson, J.R., Liebig, M.A., and Berdahl, J.D. (2008b). Responses of Medicago sativa and M. falcata type alfalfas to different defoliation times and grass competition. Can. J. Plant. Sci. 88: 61-69.

Hendrickson, J.R., Schmer, M.R., and Sanderson, M.A. (2013). Water use efficiency by switchgrass compared to a native grass or a native grass alfalfa mixture. Bioenergy Res. 6: 746-754.

High Plains Climate Center (2019). High Plains Regional Climate Center, CLIMOD page. http://climod.unl .edu (accessed 10 October 2019).
Holechek, J.L. (1988). An approach for setting the stocking rate. Rangelands 10: 10-14.

Holechek, J.L., Pieper, R.D., and Herbel, C.H. (1998). Range Management Principles and Practices, 3e. New Jersey: Prentice Hall.

Howard, J.L. (1996). Bromus inermus. In: Fire Effects Information System [Online]. U.S. Department of Agriculture, Forest Service, Rocky Mountain Research Station, Fire Sciences Laboratory (Producer) Available: https://www.fs.fed.us/database/feis/plants/graminoid/ broine/all.html. Accessed Feb. 20, 2019.

Huston, J.E. and Pinchak, W.E. (1991). Range animal nutrition. In: Grazing Management: An Ecological Perspective (eds. R.K. Heitschmidt and J.W. Stuth), 27-63. Portland, OR: Timber Press.

Jensen, K.B., Singh, D., Bushman, B.S., and Robins, J.G. (2015). Registration of 'Arsenal' meadow bromegrass. J. Plant Regist. 9: 304-310.

Jordan, D.J., Klopfenstein, T.J., and Adams, D.C. (2002). Dried poultry waste for cows grazing low-quality winter forage. J. Anim. Sci. 80: 818-824.

Karn, J.F. and Ries, R.E. (2002). Free-choice grazing of native range and cool-season grasses. J. Range Manage. 55: 469-473.

Klett, W.E., Hollingsworth, D., and Schuster, J.L. (1971). Increasing utilization of weeping lovegrass by burning. J. Range Manage. 24: 22-24.

Kline, K.L., Singh, N., and Dale, V.H. (2013). Cultivated hay and fallow/idle cropland confound analysis of grassland conversion in the Western Corn Belt. Proc. Natl. Acad. Sci. U.S.A. 110: E2863-E2863.

Knox, F.W., Burton, G.W., and Baird, D.M. (1958). Effects of $(\mathrm{N})$ rate and clipping frequency upon lignin content and digestibility of coastal bermudagrass. Agric. Food Chem. 6 (2): 217-218.

Laingen, C.R. (2015). Measuring cropland change: a cautionary tale. Pap. Appl. Geogr. 1: 65-72.

Lardy, G.P., Adams, D.C., Klopfenstein, T.J., and Clark, R.T. (1999). First limiting nutrient for summer calving cows grazing autumn-winter range. J. Range Manage. 52: 317-326.

Lark, T.J., Salmon, J.M., and Gibbs, H.K. (2015). Cropland expansion outpaces agricultural and biofuel policies in the United States. Environ. Res. Lett. 10 https:// doi.org/10.1088/1748-9326/10/4/044003.

Larson, D.M., Martin, J.L., Adams, D.C., and Funston, R.N. (2009). Winter grazing system and supplementation during late gestation influence performance of beef cows and steer progeny. J. Anim. Sci. 87: 1147-1155.

Lauenroth, W.K., Burke, I.C., and Gutmann, M.P. (1999). The structure and function of ecosystems in the Central North American grassland region. Great Plains Res. 9: 223-259.

Launchbaugh, J.L., Owensby, C.E., Schwartz, F.L., and Corah, L.R. (1978). Grazing management to meet 
nutritional and functional needs of livestock. In: Proceedings of the First International Rangeland Congress (ed. D.N. Hyder), 541-546. Denver, CO.

Liebig, M.A., Hendrickson, J.R., Franco, J.G. et al. (2018). Near-surface soil property responses to forage production in a semiarid region. Soil Sci. Soc. Am. J. 82: 223-230.

Lorenz, R.J. (1976). Resource combination and technological innovations for beef cattle enterprises in the Northern Great Plains. In: Integration of Resources for Beef Cattle production. Proc. Symp. Society of Range Management 29th Annual Meeting, 37-52. Feb 16-20, 1976. Omaha, NE.

Lorenz, R.J. (1977). Complementary grazing systems for the Northern Great Plains. In: Proc. the Range Beef Cow Symposium V, 29-39. Dec. 12-14, 1977, Chadron, NE.

Malinowski, D.P., Hopkins, A.A., Pinchak, W.E. et al. (2003). Productivity and survival of defoliated wheatgrasses in the Rolling Plains of Texas. Agron. J. 95: 614-626.

Martins, A.P., Cecagno, D., Borin, J.B.M. et al. (2016). Long-, medium- and short-term dynamics of soil acidity in an integrated crop-livestock system under different grazing intensities. Nutr. Cycling Agroecosyst. 104: 67-77.

Mattupalli, C., Moffet, C.A., Shah, K., and Young, C. (2018). Supervised classification of RGB aerial imagery to evaluate the impact of a root rot disease. Remote Sens. 10: 917. https://doi.org/10.3390/rs10060917.

McIlvain, E.H. (1976). Seeded grasses and temporary pasture as a complement to native rangeland for beef cattle production. Integration of Resources for Beef Cattle Production Symposium. Proc. 29 $9^{\text {th }}$ Annual Meeting, Society for Range Management.

McMurphy, W.E., Denman, C.E., and Tucker, B.B. (1975). Fertilization of native grass and weeping lovegrass. Agron. J. 67: 233-236.

Monono, E.M., Nyren, P.E., Berti, M.T., and Pryor, S.W. (2013). Variability in biomass yield, chemical composition, and ethanol potential of individual and mixed herbaceous biomass species grown in North Dakota. Ind. Crops Prod. 41: 331-339.

Moore, K.J., Hintz, R.L., Wiedenhoeft, M.H. et al. (2004). Complementary grazing systems for beef cattle production. Leopold Center Completed Grant Reports No. 228.

Myers, R. and Watts, C. (2015). Progress and perspectives with cover crops: interpreting three years of farmer surveys on cover crops. J. Soil Water Conserv. 70: 125A-129A.

Ogden, R.K., Coblentz, W.K., Coffey, K.P. et al. (2005). Ruminal in situ disappearance kinetics of dry matter and fiber in growing steers for common crabgrass forages sampled on seven dates in northern Arkansas. J. Anim. Sci. 83: 1142-1152.

Orton, R.B. (1974). The climate of Texas. In: Climates of the States: Volume II: Western States Including Alaska and Hawaii (ed. Officials of the U.S. Department of Commerce). Port Washington, NY: Water Information Center, Inc.

Padbury, G., Waltman, S., Caprio, J. et al. (2002). Agroecosytems and land resources of the Northern Great Plains. Agron. J. 94: 251-261.

Prine, G.M. and Burton, G.W. (1956). The effect of (N) rate and clipping frequency upon yield, protein content and certain morphological characteristics of coastal bermudagrass. Agron. J. 48: 296-301.

Rakkar, M.K. and Blanco-Canqui, H. (2018). Grazing of crop residues: impacts on soils and crop production. Agric. Ecosyst. Environ. 258: 71-90.

Rasby, R., Selley, R. and Klopfenstein, T. (1998). Grazing crop residues. Nebraska Cooperative Extension Bulletin No. EC 98-278-B.

Raub, R.H. (2018). The back-yard horse owner and the equine industry at large. J. Anim. Sci. 96 (Suppl. 2): 33-34.

Redfearn, D.D., Parsons, J., Drewnoski, M. et al. (2019). Assessing the value of grazed corn residue for crop and cattle producers. Agric. Envir. Lett. 4: 180066. https:// doi.org/10.2134/ael2018.12.0066.

Redmon, L.A., Horn, G.W., Krenzer, E.G. Jr., and Bernardo, D.J. (1995). A review of livestock grazing and wheat grain yield: boom or bust? Agron. J. 87: 137-147.

Reuter, R.R. and Horn, G.W. (1999). Cool-season perennial grasses as complementary forages to winter wheat pasture. Prof. Anim. Sci. 18: 44-51.

Rocateli, A. (2017). Fertilizing warm-season forages. In: Oklahoma Forage and Pasture Fertility Guide, E-1021 (eds. B. Arnall and A. Rocateli), 32-43. Oklahoma Cooperative Extension Service Division of Agricultural Sciences and Natural Resources Oklahoma State University.

Sala, O.E., Parton, W.J., Joyce, L.A., and Lauenroth, W.K. (1988). Primary production of the central grassland region of the United States. Ecology 69: 40-45.

Sanderson, M., Johnson, H., and Hendrickson, J. (2018). Cover crop mixtures grown for annual forage in a semi-arid environment. Agron. J. 110: 525-534.

Scharf, P.C., Shannon, D.K., Palm, H.L. et al. (2011). Sensor-based nitrogen applications out-performed producer-chosen rates for corn in on-farm demonstrations. Agron. J. 103: 1683-1691. https://doi.org/10 .2134/agronj2011.0164.

Schmer, M.R., Brown, R.M., Jin, V.L. et al. (2017). Corn residue use by livestock in the United States. Agric. Envir. Lett. 2: 160043. https://doi.org/10.2134/ ael2016.10.0043. 
Schubert, S.D., Suarez, M.J., Pegion, P.J. et al. (2004). Causes of long-term drought in the U.S. Great Plains. J. Clim. 17: 485-503.

Shelton, E.M. (1888). Experiments with wheat. Kansas Agricultural Experiment Station Research Report 4.

Sims, P.L. (1993). Cow weights and reproduction on native rangeland and native rangeland-complementary forage systems. J. Anim. Sci. 71: 1704-1711.

Smoliak, S. and Johnston, A. (1980). Russian wildrye lengthens the grazing season. Rangelands 2: 249-250.

Soil Survey Staff (1999). Soil Taxonomy: A Basic System of Soil Classification for Making and Interpreting Soil Surveys, 2e. USDA-NRCS Agricultural Handbook No. 436. Washington, D.C: U.S. Government Printing Office.

Stalker, L.A., Blanco-Canqui, H., Gigax, J.A. et al. (2015). Corn residue stocking rate affects cattle performance but not subsequent grain yield. J. Anim. Sci. 93: 4977-4983.

Stubbs, M. (2015). Irrigation in U.S. Agriculture : On - farm Technologies and Best Management Practices (No. 7-5700 R44158).

Swinton, S.M., Babcock, B.A., James, L.K., and Bandaru, V. (2011). Higher US crop prices trigger little area expansion so marginal land for biofuel crops is limited. Energy. Policy 39: 5254-5258.

Taylor, J.L., Acevedo, W., Auch, R.F. and Drummond, M.A. (2015). Status and trends of land change in the Great Plains of the United States-1973 to 2000. U.S. Geological Survey Professional Paper, 1794-B. http:// dx.doi.org/10.3133/pp1794B.

Thornthwaite, C.W. (1931). The climates of North America: according to a new classification. Geog. Rev. 21: 633-655.

Thornthwaite, C.W. (1941). Climate and settlement in the Great Plains. In: 1941 Yearbook of Agriculture. Climate and Man (ed. E. Raisz), 177-187. Washington, D.C.: US Department of Agriculture.

Titlow, A., Luebbe, M.K., Lyon, D.J. et al. (2014). Using dryland annual forage mixtures as a forage option for grazing beef cattle. Forage and Grazinglands 12: 1-6.

Toledo, D., Sanderson, M., Spaeth, K. et al. (2014). Extent of Kentucky bluegrass and its effect on native plant species diversity and ecosystem services in the Northern Great Plains of the United States. Invasive Plant Sci. Manage. 7: 543-552.

Trimble, D.E. (1980). The Geologic Story of the Great Plains. Geological Survey Bulletin 1493. Reston, VA: U.S. Geological Survey.

Twidwell, E.K., Boe, A. and Casper, D.P. (2002). Teff: A new annual forage grass for South Dakota? Exten- sion Extra. Paper 278. http://openprairie.sdstate.edu/ extension_extra/278 (accessed 22 November 2019).

USDA National Agricultural Statistics Service. (2014). 2012 Census of Agriculture. Report AC-12-A-51. Washington, DC. https://www.nass.usda.gov/ AgCensus (accessed 10 October 2019).

USDA National Agricultural Statistics Service. (2019). Quick Stats. USDA-NASS. https://quickstats.nass .usda.gov/results/83473400-CED9-3E7D-BE9FC372D6031701 (accessed 10 October 2019).

Vallentine, J.F. (1989). Range Development and Improvements, 3e. San Diego, CA: Academic Press, Inc.

Vogel, K.P. and Hendrickson, J.R. (2019). History of grass breeding for grazing lands in the Northern Great Plains of the USA and Canada. Rangelands 41: 1-16.

Vogel, K.P., Moore, K.J., and Moser, L.E. (1996). Bromegrasses. In: Cool-Season Forage Grasses (eds. L.E. Moser, D.R. Buxton and M.D. Casler), 535-567. Madison, WI: ASA, CSSA, SSSA.

Volesky, J.D., Mowrey, D.P., and Smith, G.R. (1996). Performance of rose clover and hairy vetch interseeded into Old World bluestem. J. Range Manage. 49: 448-451.

Walthall, C.L., Hatfield, J., Backlund, P. et al. (2012). Climate Change and Agriculture in the United States: Effects and Adaptation, 186. Washington, DC: USDA Technical Bulletin 1935.

Warren, J., Lalman, D., Mcgee, A. et al. (2018). Managing Crabgrass in a Continuous Grazeout Wheat System. PSS 2790. Stillwater, OK: Oklahoma Cooperative Extension Service. Division of Agricultural Sciences and Natural Resources, Oklahoma State University.

Merriam-Webster (1990). Webster's Ninth New Collegiate Dictionary. Springfield, MA: Merriam-Webster, Inc.

Wedin, D.A. and Tilman, D. (1996). Influence of nitrogen loading and species composition on the carbon balance of grasslands. Science 274: 1720-1723.

Wright, H.A. (1988). Role of fire in the management of southwestern ecosystems. In: Effects of Fire Management of Southwestern Natural Resources. USDA Forest Service General Technical Report RM-191 (ed. J.S. Krammes), $1-5$.

Wright, C.K. and Wimberly, M.C. (2013). Recent land use change in the Western Corn Belt threatens grasslands and wetlands. Proc. Natl. Acad. Sci. U.S.A. 110: 4134-4139.

Wright, C.K., Larson, B., Lark, T.J., and Gibbs, H.K. (2017). Recent grassland losses are concentrated around US ethanol refineries. Environ. Res. Lett 12 044001. 